\title{
The Effects of Some Metals in Acidified Waters on Aquatic Organisms
}

\author{
Tembo Rostern N \\ Department of Biological Sciences, Western Kentucky University, USA
}

Submission: September 08, 2017; Published: September 25, 2017

*Corresponding author: Rostern NT, Department of Biological Sciences, Western Kentucky University, USA, Tel: 270-745-6000;

Email: rostern.tembo@wku.edu

Abstract

Mining metals or extraction of metals is an important process in our modern way of life. There are phases in the life of a mine that can discharge metals to estuaries, rivers, lakes and eventually oceans. These metals dissolve in water (very easily in acidified waters) and are either directly absorbed by fish and other aquatic organisms or indirectly absorbed from food chains. Small concentrations (levels) of metals can be toxic because metals undergo bio-concentration, which means that metal concentration in organisms gets higher than in water. The mobilization of metals in soluble forms from the soil to the aquatic ecosystem is an important consequence of acidification of lakes and streams. Heavy metals are generally less toxic at circum neutral pH but very toxic at low $\mathrm{pH}$. This paper reviews the effects on these heavy metals in acidic (low pH) waters on fish and other aquatic organisms, and the consequences on human health as a result of humans being on top of the food chain. A lot of research has been done on the effect of heavy metals on human health and that's not my reason for writing this paper, my aim has been to explore another path, which is how acidification of oceans, seas and rivers exacerbates the mobilization of metals into water bodies and how the acidic waters (low $\mathrm{pH}$ ) have contributed to changing the metallic states into more lethal forms of metals - the metallic ions.

Keywords: Low pH; Aquatic organisms; Metal ions; Toxic; Acidified; Concentration

\section{Introduction}

In my previous publication on the impact of ocean acidification on aquatic organisms, I wrote: "Many aquatic organisms, olfactory-mediated behavior is essential to the maintenance of numerous fitness-enhancing activities, including foraging, reproduction and predator avoidance. Studies in both freshwater and marine ecosystems have demonstrated significant impacts of anthropogenic acidification on olfactory abilities of fish and macro invertebrates, leading to impaired behavioral responses, with potentially far-reaching consequences to population dynamics and community structure. Ocean acidification represents a threat to marine species worldwide, and forecasting the ecological impacts of acidification is a high priority for science, management, and policy makers [1].”

In this current review paper I would like to proceed as a continuation (sequel) of my previous paper but now focusing much on the impact of acidified water (low $\mathrm{pH}$ ) (bearing in mind also that the water temperatures are rising due to global warming) on natural occurring metals and how these interactions can further exacerbate the current impact by ocean acidification on aquatic organisms. Acid rain and $\mathrm{CO} 2$ acidification of the oceans plus their adverse effects on aquatic organisms have been well documented [1]. One of the most valuable resources on our planet is water and the purity of it should be everyone's concern and responsibility as it affect's human welfare. Both inorganic and organic compounds can enter into water bodies and change the purity of water and consequently affect aquatic organism including human beings who are at the top of the food chain. Major components of inorganic contaminants would include metals and heavy metals whose pollution of the sea is less visible and direct than other types of marine pollution but its effects on marine ecosystem and humans are very extensive [3-5]. Industrial wastes constitute the major source of metal pollution in natural water [6].

\section{Aluminum}

Aluminum naturally occurs as bauxite, aluminum hydroxide or can be oxidized to aluminum oxide and is one of the most abundant element in the soil and rarely does it occur in water at concentrations greater than a few tenths of a milligram per liter. However, higher concentrations can occur as a result of drainage from coal mines, acid precipitation and break 
down of clays [7]. The mobilization of aluminum in soluble forms from the soil to the aquatic ecosystem is an important consequence of acidification of lakes and streams [8-12]. The $\mathrm{pH}$ and concentration of inorganic aluminum are the key factors for toxicity in acid waters [13]. The chemistry of aluminum compounds in water is complex but can combine with organic and inorganic ions and be in water in several forms.

$$
\begin{aligned}
& \mathrm{CO}_{2}(\mathrm{~g})+\mathrm{H}_{2} \mathrm{O}(\mathrm{l}) \leftrightarrow \mathrm{H}_{2} \mathrm{CO}_{3}(\mathrm{aq}) \\
& \mathrm{H}_{2} \mathrm{OCO}_{3}(\mathrm{aq}) \leftrightarrow \mathrm{HCO}_{3}-(\mathrm{aq})+\mathrm{H}^{+}
\end{aligned}
$$

The hydrogen ion can react with aluminum oxide or bauxite to release aluminum ions. It is least soluble at a $\mathrm{pH}$ between 5.7 and 6.2; above and below this range, aluminum tends to be in solution $[7,14]$. Aluminum has the most severe adverse effects on aquatic life, research has shown that a combination of $\mathrm{pH}$ less than 5.5 and dissolved aluminum concentration greater than $0.5 \mathrm{mg} / \mathrm{L}$ will generally eliminate all fish and many macro in vertebrates. The concentration of aluminum is highest in acidified lakes and oceans and in these water bodies the number of fish and amphibians is declining due to reactions of aluminum ions with proteins in the gills of fish and the embryos of frogs. Higher concentrations of aluminum does not only affect fish but also birds and other animals that consume contaminated fish and insects. Aluminum ions can also react with phosphates which causes phosphates to be less available to water organisms. There is a growing indication in the scientific community that aluminum can damage the roots of trees when it is located in the groundwater.

A higher concentration of aluminum correlates with aluminum accumulation in fish organs like kidney, skeleton and gills. Such accumulation in different organs may have some negative effects depending on total aluminum concentrations unlike direct toxic effects of ionic aluminum form [9]. It has also been found to be associated with the brain and heart of the rainbow trout due to chronic exposure resulting in the systematic accumulation causing a distinct neuropathology in the brain [15]. Sometimes aluminum may reduce the number of skin mucus cells associated with modification of the skin and gills and consequently reduces the activities of the gill enzymes leading to failure of the osmoregulatory system [16-18]. In human beings the uptake of aluminum can take place through food, through breathing contaminated air (especially in companies that work with aluminum) and by skin contact. Significant concentration of aluminum can lead to serious health effects such as: damage to the central nervous system, dementia, the loss of memory, listlessness accompanied by severe trembling.

\section{Iron}

Iron - Naturally exists as a soluble ferrous iron $\left(\mathrm{Fe}^{2+}\right)$ and an insoluble ferric particulate iron $\left(\mathrm{Fe}^{3+}\right)$. It is required for many physiological functions in body organs and its homeostasis is strictly regulated by various mechanisms. In oxygenated water, insoluble ferric $\left(\mathrm{Fe}^{3+}\right)$ iron dominates over the bivalent form $\mathrm{Fe}^{2+}$ ), which is toxic to aquatic animals [19]. The $\mathrm{pH}$ of water is very important because it can determine solubility and biological availability of nutrients, specifically metals such as iron. Solubility refers to the amount of a substance that can be dissolved in water and the lower the $\mathrm{pH}$ level, the more soluble the iron will be. Biological availability is the amount of a substance, which can be utilized by aquatic life. There are two main reasons why iron is more bio-available (often to the point at which it becomes toxic to life forms) at low $\mathrm{pH}$.

I. In extremely acidic environments, both natural and man-made are often associated with the oxidative dissolution of sulfide minerals, many of which contain iron (pyrites; $\mathrm{FeS}_{2}$ ).

II. Both ionic forms of iron are far more soluble (especially ferric ion) at low $\mathrm{pH}$ than at circum-neutral $\mathrm{pH}$ [20].

Iron solubility in water depends on $\mathrm{pH}$, oxidation-reduction potential, temperature, oxygen and the presence of substances to which it will bind such as $\mathrm{OH}^{-}, \mathrm{SO}_{4}^{2-}, \mathrm{Cl}^{-}$and humic substances.

$4 \mathrm{Fe}+3 \mathrm{O}_{2}+6 \mathrm{H}_{2} \mathrm{O}->4 \mathrm{Fe}^{3+}+12 \mathrm{OH}^{-}>4 \mathrm{Fe}(\mathrm{OH})_{3}$ or $4 \mathrm{FeO}(\mathrm{OH})+4 \mathrm{H}_{2} \mathrm{O}$

Ferrous Iron can precipitate at lower $\mathrm{pH}$ than aluminum and can be present in water with a $\mathrm{pH}$ of less than 4.5 making the separation of the effect of iron from the effect of low $\mathrm{pH}$ difficult.

The precipitate of ferric hydroxide may result in a complete blanketing of the ocean or stream bottom, adversely affecting both macro invertebrates and fish [21]. The severity is dependent on the ocean/stream $\mathrm{pH}$ and the thickness of the precipitate. The toxicity of iron depends on the species and the size of fish. The gills of fish act as mechanical filters, the small particles of iron with dimensions of a few microns are trapped in the gill lamella. This is why the species and size of the fish are of importance. The presence of the small ferric iron particles cause irritation of the gill tissues leading to gill damage and secondary bacterial and fungal infections. Iron acts like a catalyst in water and does promote the dissociation of oxygen molecules into free radicals. The free radicals are extremely reactive and short lived. However, on the surface of the gills, the free radicals formed by the iron causes oxidation of the surrounding tissue and this leads to massive destruction of gill tissue and anemia. Iron has been shown to induce oxidative stress [22].

Li et al. in 2009 [23] observed lipid peroxidation (LPO) and alterations in antioxidant enzyme activity in embryonic and adult medaka oryzias latipes exposed to nano-iron. After an iron enriched diet, lipid peroxidation (LPO) was observed in the liver and heart of the African catfish (clarias garie pinus) [24]. High levels of LPO were found in erythrocytes of chichlid fish from a river containing high levels of iron [25]. The deleterious effects of iron include DNA damage, lipid peroxidation (LPO) and oxidation of proteins. A higher concentration of iron in the human body can cause is hemochromatos and resulting in end organ damage [2]. 


\section{Copper}

Copper is an essential micronutrient necessary for a wider range of metabolic processes in both prokaryotic and eukaryotes. Despite copper being a required trace element, at an elevated levels copper becomes toxic, and therefore copper levels in natural environments and its biological availability are important. To be of use to biological systems, copper must be available readily in soluble form. The ionic form of copper, and its biological availability depends on environmental factors such as $\mathrm{pH}$ and redox potential, soil and sediments type, water hardness and organic contents. These factors can vary in the environments giving rise to possible conditions of either copper deficiency or copper toxicity. Copper toxicity to fish and its bioavailability increases in low $\mathrm{pH}$ (acidic) waters. The concentration of free copper, cupric ion (II) increases with acidity of water [25], and any water high in alkalinity, $\mathrm{pH}$, and organic substances will have low cupric ion concentrations. This therefore means knowledge of $\mathrm{pH}$ of a certain body of water and deciding which complex will form, one should be able to predict the toxicity of the copper. The cellular toxicity of copper is seen through its participation in what we call the Fenton reaction. Copper (I) ion can catalyze the formation of hydroxyl radicals that are very reactive to surrounding areas in order to balance their unpaired electrons (though short lived) [26]. Copper in ionic form is very poisonous for the process of photosynthesis and the growth of unicellular algae at a concentration of copper ions found in natural waters, what more in acidified waters of our oceans lakes and rivers? The copper salts combine with proteins present in the mucus of fish's mouth, gills and skin preventing aeration of the blood and death can occur [27]. Turnbull noted the copper precipitate clinging to fish which in turn exhibited weeks of periodic spasm. Copper ions can induce morphological changes in fish according to Benoit who in 1975 [28] examined the gills, liver and kidneys of bluegill that were exposed to copper solution. This was similar to Backer's study of the winter flounder in 1969 [29] where he found gross morphological changes in the gills, fatty metamorphosis of the liver and necrosis of the kidney.

\section{Zinc}

Zinc is one of the abundant trace element found in air, water and soil, toxic in some cases butalso has some useful physiological functions (e.g. in diet for normal growth and maturation, cell metabolism, development of reproductive organs. Zinc enters the air, water, and soil from natural processes and anthropogenic activities such as manufacturing metal, zinc chemical industries, domestic waste water and run-off from soil can release zinc into water bodies. Zinc dissolves in aqueous acids or bases forming hydrogen gas and zinc ate ion respectively. Much of the zinc in water bodies settle at the bottom while small amount may remain dissolved in water or as fine suspended particles. The level of dissolved zinc ions in water may increase as the acidity of ocean water increases (as $\mathrm{pH}$ decreases). The increased zinc ions in water is very lethal and increased acidity (decrease in $\mathrm{pH}$ ) in oceans and lakes means more lethality. Elevated concentrations of zinc ions in water are particularly toxic to many species of algae, crustaceans and salmonids. Elevated water concentrations of zinc have specially strong impacts on macro invertebrates such as mollusks, crustaceans, odonates and ephemeropterans. Speciation of zinc $(\mathrm{Zn})$ in waters is modulated by $\mathrm{pH}$ and by dissolved organic matter (DOM), which typically binds most aqueous Zinc. In most natural waters the free $\mathrm{Zn} 2+8$ ion is the dominant inorganic Zinc species. Total Zinc concentrations in natural waters span six orders of magnitude and are heavily influenced by human activities. Lethality of waterborne $\mathrm{Zn}$ to fish is caused by the free $\mathrm{Zn} 2+8$ ions, while dissolved organic matter (DOM), calcium, and $\mathrm{pH}$ in the water are the principal factors modifying Zinc toxicity. The ameliorating influence of water chemistry has therefore been included in some legislation governing permissible concentrations of $\mathrm{Zn}$ in natural waters. The principal mode of action for acute Zinc toxicity to freshwater fish is inhibition of calcium uptake. Little is known about mechanisms of sub-lethal toxicity in fish; however, lethality is often a sensitive endpoint also in chronic exposures of freshwater fish. Although a potentially toxic element, Zinc is essential for all known life forms. It is a cofactor of $10 \%$ of all proteins and functions as both a par cellular and an intracellular signaling substance. There is therefore a comprehensive set of proteins that function as transporters, chelators, and molecular sensors for $\mathrm{Zn}$. This regulatory network includes two large families of transporters (the solute carriers Slc30; Slc39), which regulate distribution of Zn2+ 8 ions throughout the body and within cells, metal lothionein and several proteins, which are either activated or inhibited by changes in concentrations of labile Zn2+ 8. These proteins are involved in regulation of Zinc uptake across gut and gill by homeostatic processes that are partially understood. A number of theories have been proposed [30-33] to explain how zinc compounds kill aquatic animals especially fish:

a. Coagulation of mucus on the gills of fish causes the breakdown of certain vital processes particularly gas exchange, nitrogenous excretion, salt balance and circulation of blood.

b. Cytology damage to the gills of fish causes similar breakdowns.

c. Zinc coagulates protoplasm, following its absorption into the bodies of aquatic animals.

d. Long exposure of fish to low concentrations of zinc, subjects them to stress which induces in essential organs adverse changes that result in death.

\section{Lead}

Lead is scattered throughout the environment as a direct result of human activities (lead gasoline, lead-based paint, lead solder in food cans, lead-arsenate pesticides, mining, manufacture of lead-containing products etc), in air it is in the 
form of particles and can be removed by rain or gravitation pull of the earth. Its compound solubility in water is a function of $\mathrm{pH}$, hardness, salinity and the presence of humid material. Lead solubility is highest in soft, acidic water. Lead has a tendency to form compounds of low solubility with major anions found in natural waters. The amount of lead dissolved in surface waters is dependent on the $\mathrm{pH}$ and the dissolved salt content of water. The maximum solubility of lead in hard water is about $30 \mu \mathrm{g} / \mathrm{L}$ at $\mathrm{pH}$ $>5.4$ and the maximum solubility (highest toxicity) of lead in soft water is approximately $500 \mu \mathrm{g} / \mathrm{L}$ at $\mathrm{pH}>5.4$ [34]. Lead is toxic to all aquatic biota, and organisms higher up in the food chain may experience lead poisoning as a result of eating lead contaminated food. Organ lead compounds such as tri-alkyl and tetra-alkyl lead compounds are more toxic than inorganic forms and have been shown to be bio-concentrate in aquatic organisms. Changes in solution chemistry particularly $\mathrm{pH}$, can have a significant impact on trace metal phase distribution. Solution $\mathrm{pH}$ is commonly considered to be the master variable governing lead metal ion adsorption to oxide surfaces [35]. Competition between Hydrogen ions $(\mathrm{H}+)$ and metal cation for available binding sites on surfaces is expected. Subsequently, reduced pH (more acidic waters) is likely to increase soluble lead in natural aquatic systems. When lead concentrations in algae exceed 500 parts per billion (ppb), enzymes needed for photosynthesis are inhibited [36]. When photosynthesis is inhibited or takes place slowly, the algae will produce little food and therefore will not grow much. Decreased algal growth means less food for animals and this has repercussions for the entire ecosystem. Fish are more sensitive to lead than algae. When lead concentration exceed $100 \mathrm{ppb}$, gill function is affected. Embryos and fry are more sensitive to the toxic effects of lead than are adults. Lead is more toxic at lower $\mathrm{pH}$ and in soft water [36,37]. Lead accumulates in the bones and tissues of fish, and in higher enough concentrations can impair the function of the liver, kidney and spleen and can cause spinal deformities and death.

\section{Mercury}

Mercury is an important pollutant of water throughout the world, and a number of human activities are linked to mercury pollution (silver and gold mining, coal combustion and dental amalgams [38]. There are two forms of mercury occurring in nature, the Organic methyl mercury (as a result of methylation of inorganic mercury by microorganisms in sediments and water and is facilitated by low $\mathrm{pH}$ and high dissolved organic carbon [37], and the inorganic (mercurous, mercuric). The methyl mercury - the organic one is the most toxic to fish than the inorganic one [37]. Methyl mercury dissolves in water, crosses biological membranes and persists in fatty tissues of organisms. In addition to bio-concentration, methyl mercury undergoes biomagnification. Each level of the food chain has a higher tissue concentration than its prey. Mercury levels at the top of the food chain are thousands or millions of times higher than in water or sediments [39]. In a paper published by Wren et al, 1983 [40] the bio-magnification of mercury in a food chain in a remote, pristine lake Ontario is illustrated: The available analytical methods did not detect mercury in the lake water, bio-concentration resulted in mercury detection in the lake organisms. Bio-magnification resulted in higher mercury levels in clams than in the sediments where they dwell, higher levels in smelt than in clams, higher levels in bass and pike than in the smelt that they eat, and highest levels in otters and waterfowl that are at the top predators in this food chain. Mercury levels in bass and pike exceeded the 0.5 parts per million (ppm) according to the Canadian federal advisory level for fish consumption. What is the fate of human beings who eat fish that have a higher concentration of mercury? Mercury is known to be a neurotoxin that causes structural damage to the brain and inhibits enzymes' activities needed for normal neurotransmission.

\section{Chromium}

Chromium in the crystal form is steel-gray, lustrous hard metal with an atomic weight of 51.996, atomic number 24 and has a density of $7.14 \mathrm{~g} / \mathrm{cm}^{3}$. It can exist in oxidation states ranging from -2 to +6 , but is mostly frequently found in the environment in the trivalent $(+3)$ and hexavalent $(+6)$ oxidation states. The +3 and +6 forms are the most important because the $+2,+4$ and +5 forms are unstable and are rapidly converted to +3 , which in turn is oxidized to +6 [41-44]. Because of chromium wide spread industrial use in the United States, it has been introduced as a byproduct or waste material in water, soil, sediments and in air. There are at least five ionic species of hexavalent chromium (Cr) of which two are: the hydro chromate ion and the chromate ion. These are the predominant species and probably the agents that are toxic to fresh water life [45]. Water $\mathrm{pH}$ drastically affects the concentration of each of these ions, as $\mathrm{pH}$ decreases from 7.8 to 6.5 the hydro chromate ion is increased by a factor of 3 and the chromate ion decreases by a factor of 6.8. At a high environmental concentrations of $\mathrm{Cr}+6$ (2.0ppm in water) and at alkaline $\mathrm{pH}$, concentrations in the rainbow trout tissues were greatest in gills, liver, kidney and digestive tract. After transfer of the fish to $\mathrm{Cr}$ free media, residues tended to remain high in kidney and liver, concentration in gill tissues tended to be greatest at $\mathrm{pH} 7.8$ than at pH 6.5 [44]. Studies with per fused gills showed that the transfer of $\mathrm{Cr}$ was directly coupled with the transfer of oxygen from external solution to the internal perfusion medium and that this transfer was significantly more rapid at $\mathrm{pH} 6.5$ than at alkaline $\mathrm{pH}$ [45]. As is the case with other metals, chromium toxicity to aquatic organisms increases as water temperature increases and as $\mathrm{pH}$ and salinity decrease. The ionization of chromium to either $\mathrm{Cr}+3$ or $\mathrm{Cr}+6$ in aquatic environment seems to be faster in acidified waters than in natural waters. Human beings exposed to chromium by drinking contaminated water with chromium or swimming in such contaminated waters experience serious health problems like mouth ulcers, nosebleeds, kidney disease, low white blood cell count, miscarriages and a variety of cancer cases [46,37]. 


\section{Conclusion}

In the previous publication, it was stated that, "A deadly recipe is brewing that threatens the survival of countless creatures throughout the earth's oceans. For years we have known that the oceans absorb about a quarter of the atmospheric carbon dioxide, but with a higher carbon dioxide emissions worldwide, this silent killer is entering into our seas at a staggering rate, raising the ocean's acidity and lowering the $\mathrm{pH}$. The combining effect of global warming and ocean acidification has unspeakable detrimental effects on coral reefs plus millions of organisms that live under acidified water. There is no doubt on my mind that sea water acidification affects the intracellular $\mathrm{pH}$ of the egg and sperm and alters sperm motility, fertilization and embryo development of many aquatic micro-organisms" [1]. To this carbon dioxide acidification (add low $\mathrm{pH}$ of ocean waters), the effect from the emission of Sulphur dioxide and nitrogen oxide that fall into oceans, seas and rivers as acid rain in winters. Metal toxicity is mostly associated with the acidification because their solubility increases dramatically when the $\mathrm{pH}$ of water is low. When water $\mathrm{pH}$ has declined due to acid rains and other acidic episodes, heavy metals can be mobilized from environments and soils and are released into the water column and become toxic to aquatic biota. The $\mathrm{pH}$ and concentration of inorganic metal ions are key factors for toxicity in these acid waters. The inorganic metals and metal ions affect nearly all levels in the physiology and behavior of fish and other aquatic organisms, the main target organs being gills, skeleton, and kidneys (in fish). In addition, low concentrations of heavy metals can cause chronic stress which may not kill individual fish, but lead to a low body weight and small size reducing their ability to compete for food and habitats. Every pollution in the aquatic environment which impacts physiology, growth or survival of fish, affects humans that are at the top of the food chain - we consume fish [47].

The accumulation of heavy metals in the tissues of organisms can result in chronic illness and cause potential damage to the human population. Metal pollution of the ocean or seas is less visible and direct than other types of marine pollution, but its effects on marine ecosystems and humans are very extensive. The presence of metals and metal ions vary between fish species, could depend on age, developmental stage, and other physiological factors. Fish accumulate substantial concentration of metals (for example mercury) in their tissues and thus can represent a major dietary source of this element for humans. Fish are the single largest source of mercury and arsenic for man. Mercury and other metals are known human toxicant and the first sources of mercury contamination in man are fishes. Bio-transformation of mercury and methyl mercury formation constitute a dangerous problem for human health [48]. You may have heard that "People who improve the quality of their diets over time should be, eating more whole grains, vegetables, fruits, nuts, and fish and less red and processed meats and sugary beverages, may significantly reduce their risk of premature death." But if the fish and other sea foods contains more concentrations of various metals such statements should be changed to exclude fish, shrimps, crabs etc. A lot of research has been done on the effect of heavy metals on human health and that's not my reason for writing this paper, my aim has been to explore another path, which is how acidification of oceans, seas and rivers exacerbates the mobilization of metals into water bodies and how the acidic waters (low $\mathrm{pH}$ ) have contributed to changing the metallic states into more lethal forms of metals the metallic ions.

The recipe which is brewing that threatens the survival of countless creatures throughout the earth's oceans will doubtlessly kill massive numbers of human beings also through consumption of heavy metal contaminated sea foods. This is unprecedented and happening at a time when the whole world has more people that are educated than it was 500 years ago. One would think that the more educated people become in the world, the safer they will be (realize the best way to live health lives for self-preservation). What is the value of going to the gym to try to be health when the next time one is on the table to eat, the food is contaminated with metals or insecticides? It appears we may stop killing each other by spears, or by nuclear weapons but fail to stop toxifying our own food (through anthropogenic activities) and hence self-destruction in the end. In some countries particularly Islands their source of food is the rivers, seas or lakes. It would be important that water quality criteria for the protection of aquatic life in all governments of different countries in the world are legislated. Specific industrial projects that apply for permits in different countries to pollute the waters by their industrial wastes should be scrutinized so that the resulting metal concentrations in receiving waters of discharge may be little or less.

\section{References}

1. Tembo $\mathrm{R}$ (2017) The Impact of Ocean Acidification on Aquatic Organisms. Journal of Environmental \& Analytical Toxicology 7: 469.

2. Tembo $R$ (2016) Discussing why Hemochromatosis is ignored: A Common but Rarely Diagnosed Disease. Internal Medicine Research Open Journal 1(1).

3. Gosh M, Singh SP (2005) Review on Phytoremediation of heavy metals and utilization of its byproducts. Applied Ecology Research 3 (1): 1-18.

4. Gad NS, Saad AS (2008) Effect of environmental pollution by phenol on some physiological parameters of oreochromis niloticus. Global veterinaria 2(6): 312-319.

5. Jadhav JP, Lalyani DC, Telke SS, Govindwa SP (2010) Evaluation of the efficacy of a bacterial consortium for the removal of color, reduction of heavy metals, toxicity from textile dye effluent. Bioresource Technol 101(1): 165-173.

6. Livingstone DR (2001) Contaminant- stimulated reactive oxygen species production and oxidative damage in aquatic organisms. Mar Pollut Bull 42(8): 656-666.

7. Hem JD (1970) Study and Interpretation of the Chemical Characteristics of Natural Waters. Geological Survey Water Supply 2254: 363. 
8. Radic N, Bralic M (1995) Aluminum floride complexation and its ecological importance in the aquatic environment. The science of the Total Environment 172(2-3): 237-243.

9. Rodushkin I, Moiseenko T, Kudravsjeva L (1995) Aluminum in the surface waters of the Kola Peninsula, Russia. The Science of the Total Environment 163(1-3): 55-59.

10. William RJP (1996) Aluminum and biological systems: An introduction. Coordination Chemistry Review 149: 1-9.

11. Alloway BJ, Ayres DC (1997) Chemical Principles of Environmental Pollution. Blackie Academic \& Professional, UK.

12. Driscoll CT, Driscoll KM, Mitchell MJ, Raynal DJ (2003) Effects of acid deposition on forest and aquatic ecosystems in New York State. Environmental Pollution 123(3): 327-336.

13. Rosseland BO, Henriksen A (1990) Acidification in Norway - loss of fish populations and 1000- lake survey 1986. The Science of the Total Environment 96(1-2): 45-56.

14. Brown DJA and Sadler K (1989) Fish survival in acid waters. In: Acid Toxicity and Aquatic Animals. Society for Experimental Biology Seminar Series 34: 31-44.

15. Exley C (1996) Aluminum in the brain and heart of the rainbow trout Journal of Fish Biology 48(4): 706-713.

16. Rosseland BO, Eldhuset TD, Staurnes M (1990) Environmental effects of aluminum. Environmental Geochemistry and Health 12(1-2): 17-27.

17. Berntssen MHG, Kroglund F, Rosseland BO, Wendelaar BSE (1997) Response of skin mucous cells to aluminum exposure at low $\mathrm{pH}$ in atlantic salmon (Salmo salar) smolts. Canadian Journal of Fisheries and Aquatic Science 54(5): 1039-1045.

18. Exley C (1998) The precipitation of mucin by aluminum. Journal of Inorganic Biochemistry 70(3-4): 195-206.

19. Davidson W (1993) Iron and manganese in lakes. Earth Science Reviews 34: 119-163.

20. Barrie D, Tadayoshi K, Sabrina H (2012) Redox transformations of iron at extremely low pH: Fundamental and applied aspects. Front microbiol 3: 96

21. Hoehn RC, Sizemore DR (1977) Acid mine drainage (AMD) and its impact on a small Virginia stream. Water Res Bull 13(1): 153-160.

22. Sevcikova M, Modra H, Slaninova A, Svobodova Z (2011) Metals as a cause of oxidative stress in fish: a review. Vet Med 56(11): 537-546.

23. Li H, Zhou Q Wu Y, Fu J, Wang T, et al. (2009) Effects of waterborne nano-iron on medaka (Oryzias latipes): antioxidant enzymatic activity, lipid peroxidation and histopathology. Ecotoxicol Environ Saf 72(3): 684-692.

24. Baker RTM, Martin P, Davies SJ (1997) Ingestion of sub-lethal levels of iron sulphate by African catfish affects growth and tissue lipid peroxidation. Aquatic Toxicology 40(1): 51-61.

25. Ruas CBG, Carvalho CD, Araujo HSS, Espindola ELG, Fernandes MN, et al. (2008) Oxidative stress biomarkers of exposure in the blood of cichlid species from a metal-contaminated river. Ecotoxicol Environ Saf 71(1): 86-93.

26. Tao S, Wen Y, Long A, Dawson R, Cao J, et al. (2001) Simulation of acid base condition and copper speciation in fish gill microenvironment Comput Chem 25(3): 215-222.

27. Turnbull H, De Man JG, Weston RM (1954) Toxicity of various refinery materials to fresh water fish. Industrial and Engineering Chemistry 46(2): 324-333.

28. Benoit DA (1975) Chronic effects of copper on survival growth and reproduction of the blue gill (Lepomis macrochirus). Transactions American Fisheries Society 104(2): 353-358.
29. Baker, Jeremy Y (1969) Histological and electron microscopical observations on copper poisoning in the winter flounder (Pseudopleuronectes americus). Journal of fisheries Research Board of Canada 26(11): 2785-2793.

30. Carpenter, Kathleen E (1930) Further researches on the action of metallic salts on fish. J Exptl Zool 56(4): 407-422.

31. Jones JRE (1947) The reactions of Pygosteus pungitius L. to toxic solutions. J Exptl Biol 24(1-2): 110-122.

32. Lloyd R (1960) The toxicity of zinc sulphate to rainbow trout. Ann Appl Biol 48(1): 84-94.

33. Crandall C,Goodnight CJ (1963) The effects of sublethal concentrations of several toxicants to the common guppy (Lebistes reticulatus). Trans. Am Microscope Soc 82(1): 59-73.

34. (EPA) (1977) Standards of performance for secondary lead smelters. U.S. Environmental Protection Agency. Code of Federal Regulations.

35. Schindler PW (1991) In Heavy Metals in the Environment. In: Vernet JP (Ed.), New York, USA.

36. Taub FB (2004) Fish 430 lectures (Biological Impacts of Pollutants on Aquatic Organisms), University of Washington, College of Ocean and Fishery Sciences, Seattle, Washington, USA.

37. Wright DA, Webourn P (2002) Environmental Toxicology. Cambridge Unversity Press, Cambridge, UK, England.

38. Luoma SN, Rainbow PS (2004) Methyl mercury. In: Metal Contamination in Aquatic Environments: Science and Lateral Management. Cambridge University Press, Cambridge, UK, England, pp. 368-392.

39. Houserova P, Kuban V, Spurny P, Habarta P (2006) Determination of total mercury and mercury species in fish and aquatic ecosystems of Moravian rivers. Verterinarni Medicina 51(3): 101-110.

40. Wren CD, McCrimmon HR, Loescher BR (1983) Examination of Bioaccumulation and Biomagnification of metals in a Precambrian Shield lake. Water, Air, and Soil Pollution 19(3): 277-291.

41. Towill LE, Shriner CR, Drury JS, Hammons AS, Holleman JW, et al. (1978) Reviews of the Environmental effects of pollutants: III chromium. U. S. Environ. Protection Agency Rep 287.

42. Langard S, Norseth T (1979) Chromium. In Friberg L, Nordberg GF, Voul VB (Eds.), Handbook on the Toxicology of Metals. Elservier/North Holland Biomedical Press pp. 383-397.

43. Ecological Analysts, Inc. 1981. The sources, chemistry, fate and effects of Chromium in aquatic environments. Avail. From American Petroleum Institute, 2101 L St. N. W., Washington, DC, USA, p. 207.

44. Van der PI, Brinkhorst MA, Koeman JH (1981) Effects of pH on the acute toxicity of hexavalent chromium to rainbow trout (Salmo gairdneri). Aquatic Toxicol 1: 129-142.

45. Van der Putte I, Part P (1982) Oxygen and chromium transfer in perfused gills of rainbow trout (Salmo gairdneri) exposed to hexavalent chromium at two different pH levels. Aquatic Toxicol 2: 31-45.

46. Brandl H (2005) Heavy metals in the environment: Origin, Interaction and Remediation. 6(1).

47. Lin HC, Hwang PP (1998) Acute and chronic effects of indium chloride (InCl3) on Tilapia (Oreochromis mossambicus) larvae. Bull Environ Contam Toxicol 61: 123-128.

48. Emami KF, Ghazi-KM, Abdollahi M (2005) Heavy metals content of canned tuna fish: Food Chemistry 93: 293-296. 

CC (i) This work is licensed under Creative DOI: 10.19080/OFOAJ.2017.04.555645
Your next submission with Juniper Publishers will reach you the below assets

- Quality Editorial service

- Swift Peer Review

- Reprints availability

- E-prints Service

- Manuscript Podcast for convenient understanding

- Global attainment for your research

- Manuscript accessibility in different formats

( Pdf, E-pub, Full Text, Audio)

- Unceasing customer service

Track the below URL for one-step submission https://juniperpublishers.com/online-submission.php 